\title{
Overcoming Project Delivery Delays in A Consulting Firm: A Knowledge Management Perspective
}

\author{
Claudia Ayu Putri \\ Department of Business Administration, SBM Institut Teknologi Bandung (ITB), Jakarta \\ e-mail: claudiaa.putri@sbm-itb.ac.id
}

\begin{abstract}
Based on Investment Coordinating Board (BKPM) press release, the investment realization in Indonesia for the period of 2015-2018 shows a positive trend. In addition, the issuance of Presidential Regulation No. 24 of 2018 related to Online Single Submission (OSS) which facilitates the issuance of licensing in Indonesia. This has a direct impact on the consulting firms, as the Foreign Investment Company (PT PMA) tends to transfer their internal activities to service provider companies to provide opportunities to fulfill their objectives to gain competitive advantage. Seeing this great potential, leads to growth in companies engaged in consulting. In Jakarta alone, there were at least 66 consulting firms which are working in similar field. During project completion, there are several obstacles causing delays in project delivery namely transfer of knowledge that was that was not carried out effectively due to changes in regulations. This research uses a qualitative method in the form of interviews processed through coding categorization, observation \& archive at a consulting firm, BDO Indonesia. Furthermore, knowledge management systems, SECI and knowledge flow are presented. The result of this research shows the importance of knowledge management perspective to overcome the project delivery delays in the consulting firm.
\end{abstract}

Keywords-Knowledge Flow, Knowledge Management System, SECI.

\section{INTRODUCTION}

$\mathrm{B}$ USINESS service outsourcing, from a conceptual perspective, is considered as the activity which allows a company which in this case is a service provider company to carry out activities transferred by the company that uses its services. Outsourcing business activities by company management can not only be justified as the way of the company to reduce costs, but it is also one of the processes which contribute on how the company met its objectives to gain its competitive advantage by allowing the company to focus on the core of its business. It is important to note that the strategic or the economic factors behind outsourcing are varied, depending on every company decisions and considerations. The types of business services outsourcing can also be varied however it mainly relates to the internal activity of the company such as accounting \& financial services, payroll, taxation, and statutory compliance [1].

Based on the Investment Coordinating Board (BKPM) press release, the investment realization in Indonesia for the period of 2015-2018 shows a positive trend [2]. The investment realization for 4 (four) years reaching IDR 2,572.30 trillion exceeding BKPM's strategic plan target of IDR 2,558.10 trillion. The flow of investment, in this case, comes from investment both domestic and foreign investment. This trend continues to be positive on the investment realization data of the first quarter, period of January-March 2019 with the total of investment at IDR 195.1 trillion, showing 5,3\% increase compared to the same period of 2018. Specifically, on Foreign Direct Investment (FDI) on Q1 2019, reached IDR 107.9 trillion [2]. Not to mention President Joko Widodo has issued Presidential Regulation Number 24 Year 2018 concerning the Online Single Submission (OSS). The OSS System is Government platform which is made to simplify the issuance of licenses \& permits in Indonesia (Indonesia Investments, 2018). This data shows the amount of interest in foreign investment in Indonesia which has a direct impact on the outsourcing service provider company.

The direct impact that occurs in the outsourcing service providers on foreign investment or foreign capital company which commonly known as PT PMA in Indonesia is due to the objectives of the use of outsourcing services itself, namely in the case of companies reducing costs and the effectiveness of the company. Meaning that the company, in this case PT PMA are able to focus on other areas related to their business with assistance of the outsourcing service providers [1].

Seeing this great potential, many consulting firm are established to fulfill the needs of these companies in their desire to outsource the company's internal activities. This has become important for the consulting firm to periodically develop their business strategies to be able to compete with the intense competition along with other service provider companies. Where in practice, many obstacles can occur during delivery of the service, therefore an accurate and effective business strategy is required to increase competitiveness in the business.

It is important to note that these obstacles can cause a delay in project delivery, which further leads to a decrease in the quality of the consulting firm, keeping in mind a large number of competitors engaged in the same type, the client's user service may be switched to another consulting firm that can provide its service with better time accuracy. Besides, with the delay in project delivery, there may be an increase 
The $1^{\text {st }}$ International Conference on Business and Engineering Management (IConBEM 2020)

February $1^{\text {st }} 2020$, Institut Teknologi Sepuluh Nopember, Surabaya, Indonesia

Table 1.

Disciplines Related to Project Delivery Delay

\begin{tabular}{ll}
\hline \hline No. & \multicolumn{1}{c}{ Disciplines } \\
\hline 1. & Operation Management \\
2. & Project Management \\
3. & Knowledge Management \\
4. & Human Capital Management \\
\hline \hline
\end{tabular}

Table 2.

Definitions of SECI

\begin{tabular}{|c|c|c|}
\hline Modes & Conversion & Definition \\
\hline Socialization & $\begin{array}{l}\text { From tacit } \\
\text { knowledge to } \\
\text { tacit knowledge }\end{array}$ & $\begin{array}{l}\text { Is described as the sharing } \\
\text { of tacit knowledge between } \\
\text { individuals through joint } \\
\text { activities instead of written } \\
\text { or verbal instructions. }\end{array}$ \\
\hline Externalization & $\begin{array}{l}\text { From tacit } \\
\text { knowledge to } \\
\text { explicit } \\
\text { knowledge }\end{array}$ & $\begin{array}{l}\text { Is described as the } \\
\text { involvement of expression } \\
\text { from tacit knowledge which } \\
\text { is converted into } \\
\text { comprehensible forms that } \\
\text { are easier to understand it } \\
\text { enabling } \\
\text { communication. }\end{array}$ \\
\hline Combination & $\begin{array}{l}\text { From explicit } \\
\text { knowledge to } \\
\text { explicit } \\
\text { knowledge }\end{array}$ & $\begin{array}{l}\text { It is a process which } \\
\text { involves the conversion of } \\
\text { explicit knowledge into } \\
\text { more complex sets of } \\
\text { explicit knowledges. }\end{array}$ \\
\hline Internalization & $\begin{array}{l}\text { From explicit } \\
\text { knowledge to } \\
\text { tacit knowledge }\end{array}$ & $\begin{array}{l}\text { It is the process of } \\
\text { conversion of explicit } \\
\text { knowledge } \\
\text { organization's } \\
\text { knowledge. }\end{array}$ \\
\hline
\end{tabular}

in costs than previously planned.Therefore, problems related to delay in project delivery need to be prevented. There are several disciplines that can be used to overcome the project delivery delay, namely in table 1.In this research, the approach of knowledge management is chosen to overcome the project delivery delay in a consulting firm, reckon that the consulting firm relies on knowledge as their most valuable assets. Therefore, during project delivery delays it can be assumed that those are related to knowledge related issues. In addition, in order to increase competitiveness in the business, consulting firm as an organization need to tackle the thorny issue of content organization, management, and optimization if they are to survive the deluge of information and knowledge that is being created, shared, stored, and accessed [3].

The researcher conducted research related to project delivery delay at one of the consulting firms namely BDO Indonesia, specifically in the Business Service Outsourcing department. BDO is a company that describes itself as one of the world's largest network of public accounting, tax and advisory firms with each BDO Member Firm has an independent legal identity in its own country with flexible personal characteristic focusing locally with global expertise network. BDO Indonesia, as one of the oldest accounting firms in Indonesia is member of BDO International Limited. Founded by Mr. Richard B. Thanubrata on December 6th, 1979 under the name of KAP Drs. Richard B. Thanubrata, until it was appointed by BDO International as member firm in Indonesia in 1992. BDO Indonesia now has serve clients for both domestic and international. The research was

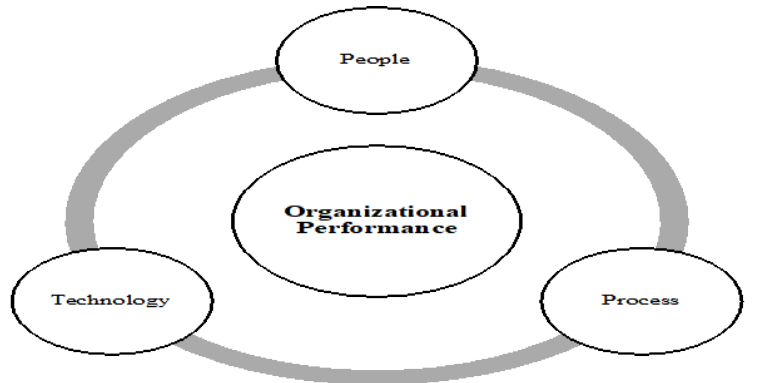

Figure 1. Knowledge Management Pillars.

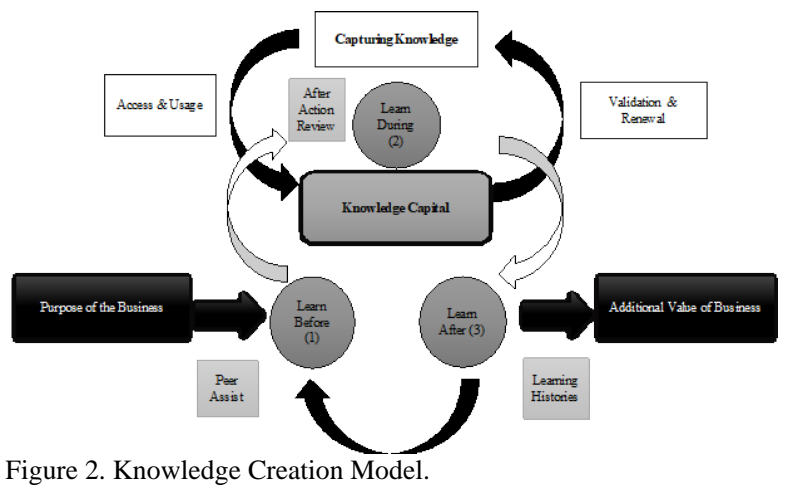

carried out in the Business Services \& Outsourcing departemen from July to October 2019.

\section{A.Theoretical Background \\ 1) Knowledge}

Knowledge is defined as information, beliefs, capacities as well as capabilities of a person or organization that makes a person or organization able to work more effectively compared to those that do not have that knowledge. Knowledge is a combination of data and information which can add to a person's opinion, skills, as well as experience during the process of creating decisions. Knowledge can be very crucial potential to a company while facing its increasingly sharp competition and has a role to improve the ability of employees to produce innovation. Knowledge is possible to be generated from the cognitive process triggered by the discovery of new information. Thus, information converted into knowledge when it is processed and thought by a human [4].

A person, individually, as well as in groups and the organization, having high competitiveness, and not to mention becoming the leading organization. Therefore, knowledge within the company must be maintained through the process of creating, using and disseminating the existing knowledge, with the principle of personnel collaboration within the company.

\section{2) Knowledge Management}

Knowledge management was initially described as the process of applying a systematic approach during the capture, structure, management and dissemination of knowledge throughout the organization in order to expedite the completion of the work, reuse best practices and reduce the cost of working on a similar project from the project that has previously done. Dalkir (2011: 7) describes knowledge management as a surprising mix of strategies, tools and 
The $1^{\text {st }}$ International Conference on Business and Engineering Management (IConBEM 2020)

February $1^{\text {st }} 2020$, Institut Teknologi Sepuluh Nopember, Surabaya, Indonesia

Table 3.

Data Collection Purposes

\begin{tabular}{|c|c|c|}
\hline No. & Data Types & Purpose \\
\hline 1. & $\begin{array}{l}\text { Interview } \\
\text { (Primary } \\
\text { Data) }\end{array}$ & $\begin{array}{l}\text { Gather information related to the research } \\
\text { concerning the background, the current situation } \\
\text { in the business, and the expected knowledge } \\
\text { management system to be implemented. } \\
\text { Interview questions consist of } 12 \text { questions } \\
\text { related to the SECI Model and People, Process \& } \\
\text { Technology. The total of interviewees is } 11 \\
\text { persons with each of them having different types } \\
\text { of responsibilities which the researcher believes } \\
\text { will be able to increase insights in answering the } \\
\text { research questions. }\end{array}$ \\
\hline 2. & $\begin{array}{l}\text { Observation } \\
\text { (Primary } \\
\text { Data) }\end{array}$ & $\begin{array}{l}\text { In this case is used to gather information and data } \\
\text { to find the existing Knowledge Management in } \\
\text { the consulting company, using the case of BDO } \\
\text { Indonesia, Business Service Outsourcing } \\
\text { department. Where researcher classified as } \\
\text { participatory study by getting involved in the } \\
\text { setting of respondents while taking notes and } \\
\text { recording. The observation is conducted by the } \\
\text { researcher for the period of July to October } 2019 \text {. }\end{array}$ \\
\hline 3. & $\begin{array}{l}\text { Archive } \\
\text { (Secondary } \\
\text { Data) }\end{array}$ & $\begin{array}{l}\text { The archive is used to gather supporting } \\
\text { information and data. The regulatory changes that } \\
\text { have an impact on the project deliveries, in this } \\
\text { case, are seen based on the publication provided } \\
\text { by the company in the form of } \\
\text { newsletter/newsflash/doing business provided by } \\
\text { the company on the company website and the } \\
\text { data from Legal Documentation and Information } \\
\text { Network (JDIH). }\end{array}$ \\
\hline
\end{tabular}

Table 4.

Interview Analysis

\begin{tabular}{|c|c|c|}
\hline No. & Grouping & "Outcomes \\
\hline 1. & $\begin{array}{l}\text { Consultant } \\
\text { Characteristics }\end{array}$ & $\begin{array}{l}\text { Characteristic mentioned are: Legal/Regulation, } \\
\text { well managed, Willingness to learn, } \\
\text { Professional, Communication, Initiative, } \\
\text { Diplomatic, Ability to explain what is needed }\end{array}$ \\
\hline 3. & $\begin{array}{l}\text { The Cause of } \\
\text { Delays in } \\
\text { Project Delivery }\end{array}$ & $\begin{array}{l}\text { The cause of delays is due to the following: } \\
\text { Change in regulation, Lack of data, Lack of } \\
\text { coordination, Minimum expertise, Manager in } \\
\text { charge responsibility, loads of work, Ineffective } \\
\text { data handover, External cause, Inability to } \\
\text { predict correct assumption. }\end{array}$ \\
\hline 4. & $\begin{array}{l}\text { What is Needed } \\
\text { to Implement } \\
\text { Knowledge } \\
\text { Management } \\
\text { System }\end{array}$ & $\begin{array}{l}\text { What is needed: Create handbook, Feedback } \\
\text { facility, Procedure/SOP, Server, Storage, } \\
\text { Project Coordinators/PIC, General meeting, } \\
\text { KPI Evaluation, Application, Specialization, } \\
\text { Knowledge center, On Job Training, HR } \\
\text { Update on CV. }\end{array}$ \\
\hline 5. & $\begin{array}{l}\text { How to } \\
\text { Implement } \\
\text { Knowledge } \\
\text { Management } \\
\text { System }\end{array}$ & $\begin{array}{l}\text { How to do it? Project Discussion, } \\
\text { Brainstorming, Open discussion, Adaptation, } \\
\text { Tutoring, Training, Informal discussion, } \\
\text { Synchronization of opinion, General Meeting } 2 \\
\text { types (Small, Big team), Transfer of knowledge } \\
\text { prior retire, Discussion with expert, Monthly } \\
\text { meeting, Consult with supervisor, Management } \\
\text { of documentation, Clear job desk, Re-use of } \\
\text { knowledge and Highly Skilled Manager. }\end{array}$ \\
\hline
\end{tabular}

techniques that encompasses everything related with knowledge, it is a multidisciplinary field. It is a combination of strategies, tools and techniques which uses a mixture of techniques from knowledge-based system design namely structured knowledge acquisition strategies from subject matter experts and educational technology, it involves everything relates to knowledge. Knowledge management enables knowledge in organizations to be placed, formalized, shared, enriched and developed, especially for the critical and strategic knowledge to stimulate innovation
Table 5.

KM Root Cause of Delays in Project Delivery

\begin{tabular}{cl}
\hline \hline No & \multicolumn{1}{c}{ Root Cause } \\
\hline 1 & $\begin{array}{l}\text { Rapid regulatory changes cannot be followed by } \\
\text { employee }\end{array}$ \\
2 & $\begin{array}{l}\text { Lack of expertise } \\
3\end{array}$ \\
4 & Nock of managerial skills \\
5 & No adaptation period \\
6 & Lack of communication and coordination \\
7 & Ineffective handover system implementation \\
8 & Lack of procedures updates \\
9 & No KM division available \\
10 & No collaborative tool available \\
\hline \hline
\end{tabular}

and creation through better knowledge productivity, optimizing the use of organizational knowledge effectively and efficiently.

\section{3) Knowledge Management System}

People, process and technology, known as knowledge management pillars, are interdependent parts of an organization which supports the management, the organization needs to motivate its people to be integrated and fully aware of the processes also to seek for continuous improvement by using the most appropriate technology to do it. Each of the elements in the KM Pillars needs to be properly integrated and have a common goal though the continuous learning process and system thinking [5] on figure 1.(a)Pillar of People: Knowledge management is embedded in the working process [5] and practiced by each individual at different levels in the organization. The top managers provide the organizational strategy with the KM program and the members as the knowledge workers use and utilize the knowledge assets as well as to seek for benefit of knowledge sharing. People are considered the heard of leveraging and creating knowledge in the organization for its competitiveness; (b)Pillar of Process: As knowledge is commonly known as tacit which has an intricate nature, it resides in the mind of individuals, the knowledge is activated from the person's repository and externalized in various formats, such as discussion, interaction and knowledge sharing it can be pooled from different sources and made into explicit knowledge. Therefore, the process of knowledge management should be incorporated in order for the organization to identify and acquire knowledge from multiple sources allowing the employees to utilize the knowledge. The structured and planned documentation including procedures enable employees to share, retrieve relevant knowledge, and assimilate new knowledge input to the existing knowledge and create new ideas to improve and enhance organizational goals. There are several processes that needs to get focused from the management; (c)Pillar of Technology: Knowledge management needs to be supported by technologies that helps the employees in the organization to communicate and collaborate, the technology needs to be able to facilitate the acquiring, codifying, indexing, updating, and disseminating knowledge among employees. The technology assist organization to process the information by dissemination of providing transparency and speed, store information 
The $1^{\text {st }}$ International Conference on Business and Engineering Management (IConBEM 2020)

February $1^{\text {st }} 2020$, Institut Teknologi Sepuluh Nopember, Surabaya, Indonesia

Table 6.

KM Objectives

\begin{tabular}{|c|c|c|c|c|c|c|c|c|c|c|c|}
\hline \multirow{2}{*}{ No } & \multirow{2}{*}{ KM Objectives } & \multicolumn{10}{|c|}{ Root Causes of Delays in Project Delivery } \\
\hline & & 1 & 2 & 3 & 4 & 5 & 6 & 7 & 8 & 9 & 10 \\
\hline 1 & Enabling employee to make better and faster decision & $\sqrt{ }$ & & & & & & & & & \\
\hline 2 & Making it easier to search relevant information and resources & & & & $\sqrt{ }$ & & & & & & \\
\hline 3 & Re-using documents ideas and expertise & & & & & $\sqrt{ }$ & & & & & \\
\hline 4 & Avoiding redundant efforts and repeating mistakes & & & & & & & & $\sqrt{ }$ & & \\
\hline 5 & Enabling organization to leverage its size & & & & & & & & & & \\
\hline 6 & Taking advantage of existing expertise & & $\sqrt{ }$ & & & & & & & & \\
\hline 7 & Communicating important information widely and quickly & & & & & & $\sqrt{ }$ & & & & \\
\hline 8 & $\begin{array}{l}\text { Providing standardized processes and procedures consistently } \\
\text { with tools and examples }\end{array}$ & & & & & & & & & & $\sqrt{ }$ \\
\hline 9 & Utilizing the expertise widely & & & & & & & $\sqrt{ }$ & & & \\
\hline 10 & Showing clients how the knowledge is used for their benefit & & & & & & & & & & \\
\hline 11 & Accelerating the client's service time & & & & & & & & & & \\
\hline 12 & Using the best problem solving & & & $\sqrt{ }$ & & & & & & & \\
\hline 13 & Stimulating innovation and growth & & & & & & & & & $\sqrt{ }$ & \\
\hline
\end{tabular}

Table 7.

People, Process \& Technology

\begin{tabular}{|c|c|c|c|c|c|c|}
\hline & \multirow{2}{*}{\multicolumn{2}{|c|}{ Root Causes }} & \multirow{2}{*}{ KM Objectives } & \multicolumn{3}{|c|}{ KM Strategies in Project Environment } \\
\hline & & & & People & Process & Technology \\
\hline \multirow[t]{3}{*}{ People } & 1 & $\begin{array}{l}\text { Rapid regulatory changes } \\
\text { cannot be followed by } \\
\text { employee }\end{array}$ & $\begin{array}{l}\text { Enabling employee to } \\
\text { make better and faster } \\
\text { decision }\end{array}$ & $\begin{array}{l}\text { Manager, } \\
\text { Consultant, } \\
\text { Associate }\end{array}$ & $\begin{array}{l}\text { Best Practice Module, } \\
\text { Lesson Learned Papers } \\
\text { (Externalization) }\end{array}$ & Portals, Podcast \\
\hline & 2 & Lack of expertise & $\begin{array}{l}\text { Taking advantage of } \\
\text { existing expertise }\end{array}$ & $\begin{array}{l}\text { Consultant, } \\
\text { Associate }\end{array}$ & Peer Assist (PA) & Groupware \\
\hline & 3 & Lack of managerial skills & $\begin{array}{l}\text { Using the best problem } \\
\text { solving }\end{array}$ & $\begin{array}{l}\text { Manager, } \\
\text { Consultant }\end{array}$ & $\begin{array}{l}\text { Checking Best Practice } \\
\text { Module, Peer Assist (PA) }\end{array}$ & $\begin{array}{l}\text { Repository, } \\
\text { Workshop }\end{array}$ \\
\hline \multirow[t]{6}{*}{ Process } & 4 & $\begin{array}{l}\text { No development program } \\
\text { for new hire }\end{array}$ & $\begin{array}{l}\text { Making it easier to } \\
\text { search relevant } \\
\text { information and } \\
\text { resources }\end{array}$ & $\begin{array}{l}\text { Manager, } \\
\text { Consultant }\end{array}$ & $\begin{array}{l}\text { Edit Procedure, Update } \\
\text { on Regulations }\end{array}$ & $\begin{array}{l}\text { Database, } \\
\text { Repository }\end{array}$ \\
\hline & 5 & No adaptation period & $\begin{array}{l}\text { Re-using documents } \\
\text { ideas and expertise }\end{array}$ & $\begin{array}{l}\text { Consultant, } \\
\text { Associate }\end{array}$ & $\begin{array}{l}\text { Checking Best Practice } \\
\text { Module \& Lesson } \\
\text { Learned Papers } \\
\text { (Internalization) }\end{array}$ & Portals, Podcast \\
\hline & 6 & $\begin{array}{l}\text { Lack of communication } \\
\text { and coordination }\end{array}$ & $\begin{array}{l}\text { Communicating } \\
\text { important information } \\
\text { widely and quickly }\end{array}$ & $\begin{array}{l}\text { Manager, } \\
\text { Consultant, } \\
\text { Associate }\end{array}$ & $\begin{array}{l}\text { Forum Discussion, } \\
\text { Brainstorming, } \\
\text { Knowledge Café } \\
\text { (Socialization) }\end{array}$ & $\begin{array}{l}\text { Email, WhatsApp } \\
\text { Group, Video } \\
\text { conference }\end{array}$ \\
\hline & 7 & $\begin{array}{l}\text { Ineffective handover } \\
\text { system implementation }\end{array}$ & $\begin{array}{l}\text { Utilizing the expertise } \\
\text { widely }\end{array}$ & $\begin{array}{l}\text { Manager, } \\
\text { Consultant, } \\
\text { Associate }\end{array}$ & $\begin{array}{l}\text { K-based exit interview } \\
\text { (Externalization) }\end{array}$ & $\begin{array}{l}\text { Database, } \\
\text { Repository }\end{array}$ \\
\hline & 8 & $\begin{array}{l}\text { Lack of procedures } \\
\text { updates }\end{array}$ & $\begin{array}{l}\text { Avoiding redundant } \\
\text { efforts and repeating } \\
\text { mistakes }\end{array}$ & $\begin{array}{l}\text { Consultant, } \\
\text { Associate }\end{array}$ & $\begin{array}{l}\text { After Action Review } \\
\text { (AAR), Learning } \\
\text { Histories (LH) }\end{array}$ & Database, Portals \\
\hline & 9 & No KM division available & $\begin{array}{l}\text { Stimulating innovation } \\
\text { and growth }\end{array}$ & $\begin{array}{l}\text { Manager, } \\
\text { Consultant, } \\
\text { Associate }\end{array}$ & $\begin{array}{l}\text { Best Practice Module, } \\
\text { Lesson Learned Papers, } \\
\text { Knowledge Café }\end{array}$ & $\begin{array}{l}\text { Intranet, } \\
\text { Groupware }\end{array}$ \\
\hline Technology & 10. & $\begin{array}{l}\text { No Collaborative Tools } \\
\text { available }\end{array}$ & $\begin{array}{l}\text { Providing standardized } \\
\text { processes and } \\
\text { procedures consistently } \\
\text { with tools and examples }\end{array}$ & $\begin{array}{l}\text { Manager, } \\
\text { Consultant, } \\
\text { Associate }\end{array}$ & Learning Histories (LH) & $\begin{array}{l}\text { Database, } \\
\text { Repository }\end{array}$ \\
\hline
\end{tabular}

securely and reliably, provide training tools to enhance rapid knowledge flows in daily business processes.

The goal of establishing balance between KM pillars of people, processes, and technology is to allow transformation of data to information, information to knowledge, accessible information and knowledge, secure knowledge assets within the organization by using the best practices and technologies, and lastly to systemize the use of knowledge for the organization's competitive advantages. Following to that, after the KM pillars has been established, the organization is also required to manage its governance. Where the governance of knowledge management [6], in strategic context connects between KM strategy to the KM implementation, it is the availability of feedback mechanism in order to improve the organization's governance process, ensuring the delivery of knowledge management strategic benefits through leaderships, risk mitigation as well as feedback mechanism. The governance of $\mathrm{KM}$ exists to ensure the KM system to meet the organization's desired performance by maintaining the performance of KM.

\section{B. Knowledge Transfer, SECI \& Knowledge Flow 1) Knowledge Transfer}

Sharing and transferring knowledge is the core of the knowledge management process, where it influences the effectiveness of the creation process which determines the growth and development process of knowledge by the organization [7]. The transfer of knowledge occurs when there are two or more people who are connected, where one gives and the other receives the knowledge. The relationship 
The $1^{\text {st }}$ International Conference on Business and Engineering Management (IConBEM 2020)

February $1^{\text {st }} 2020$, Institut Teknologi Sepuluh Nopember, Surabaya, Indonesia

\begin{tabular}{|c|c|}
\hline & $\begin{array}{c}\text { Table } 8 . \\
\text { SECI }\end{array}$ \\
\hline Socialization & Externalization \\
\hline $\begin{array}{ll}\text { - } & \text { Training } \\
\text { - } & \text { Mentorship } \\
\text { - } & \text { On-the-job Training } \\
\text { - } & \text { Forum Discussion } \\
\text { - } & \text { Brainstorming } \\
\text { - } & \text { Knowledge Café }\end{array}$ & $\begin{array}{ll}\text { - } & \text { Handover documents } \\
\text { - } & \text { Exit Interview, Draft Procedure } \\
\text { - } & \text { Draft Calendar } \\
\text { - } & \text { Draft Newsletter } \\
\text { - } & \text { Best Practice Module } \\
\text { - } & \text { K-based exit interview } \\
\text { - } & \text { Lesson Learned Papers } \\
\end{array}$ \\
\hline \multicolumn{2}{|l|}{ Combination } \\
\hline $\begin{array}{ll}\text { - } & \text { Hard-disk } \\
\text { - } & \text { Intranet } \\
\text { - } & \text { Database/Server } \\
\text { - } & \text { Edit Procedure } \\
\text { - } & \text { Update on Regulation } \\
\end{array}$ & $\begin{array}{l}\text { - } \text { Websites } \\
\text { - Checking Procedures } \\
\text { - Checking Best Practice Module } \\
\text { - } \text { Checking Lesson Learned Papers }\end{array}$ \\
\hline
\end{tabular}

Table 9.

Knowledge Flow

\begin{tabular}{|c|c|c|c|}
\hline \multirow[b]{2}{*}{$\begin{array}{l}\text { Knowledge } \\
\text { Flow }\end{array}$} & Learn Before & "Learn During & Learn After \\
\hline & Purpose of the Business & $\begin{array}{l}\text { Capturing } \\
\text { Knowledge }\end{array}$ & Additional Value of Business \\
\hline Definitions & $\begin{array}{l}\text { Effort to replicate the best practices } \\
\text { on previous projects. }\end{array}$ & $\begin{array}{l}\text { Used to minimize the errors } \\
\text { or detect as early as possible. }\end{array}$ & $\begin{array}{l}\text { Effort to record core or special events from the } \\
\text { experience of a project that has been completed. }\end{array}$ \\
\hline & Peer Assist & After Action Review & Learning Histories \\
\hline Implementation & $\begin{array}{l}\text { Before begin with the project, } \\
\text { discuss the project plan proposal to } \\
\text { the consultant/ manager who had } \\
\text { worked with similar project in the } \\
\text { past. }\end{array}$ & $\begin{array}{l}\text { Process to capture the } \\
\text { experiences or knowledges } \\
\text { during the period of } \\
\text { implementation. }\end{array}$ & $\begin{array}{l}\text { To record the experiences or knowledges of the } \\
\text { whole project after it has been completed as a } \\
\text { preparation plan material and implementation of } \\
\text { the other similar project. }\end{array}$ \\
\hline How? & $\begin{array}{l}\text { Meeting by the Consultant/Manager } \\
\text { and discuss the project plan }\end{array}$ & $\begin{array}{l}\text { All members involve evaluate } \\
\text { the experience. }\end{array}$ & $\begin{array}{l}\text { Evaluation of the whole project with the team } \\
\text { members in the form of interview, by choosing the } \\
\text { selected respondent. }\end{array}$ \\
\hline Process & Workshop & Experience Evaluation & Interview \\
\hline Result & $\begin{array}{l}\text { Statement of the purpose and } \\
\text { recommendation concerning the } \\
\text { project completion. }\end{array}$ & $\begin{array}{l}\text { Knowledge asset in the form } \\
\text { of best practices that can be } \\
\text { replicated (if it is an error, to } \\
\text { be avoided) as guidance. }\end{array}$ & $\begin{array}{l}\text { Knowledge asset in the form of guidance for future } \\
\text { project concerning the project background, list of } \\
\text { project team members, archive and key of success. }\end{array}$ \\
\hline
\end{tabular}

carried out where both parties learn from each other to grow and improve each other's knowledge.

\section{2) Knowledge Conversion Mechanism (SECI)}

Knowledge creation is definded as a spiral process of knowledge which starts at the individual level and move up across sectional, departmental, divisional and organizational boundaries [8]. SECI process (Nonaka, 1994: 18) started with the assumption that knowledge is created through conversion between tacit and explicit knowledge which allows 4 (four) types of knowledge conversion. The basic concept underlying the SECI process is that knowledge is first created within the individuals, which is then transmitted to the organization. The knowledge conversion is a social interaction between individuals, and it is not confined within an individual, on table 2.

3) Knowledge Flow

Knowledge flows is defined as the type of communication that is connected to the diffusion of messages, products, individuals as well as the organization that comes up with new ideas, knowledge, concepts and so on [9] . The flows occur when an idea formed by a particular organization through the process of learning based on ideas from other organizations and combining these ideas internally and developing these ideas with the existing ideas in the organization so that the expansion of the existing stock of ideas occurs. Knowledge flows are needed to be able to describe the whole process of knowledge management in organizations, especially in terms of the pattern of new knowledge, collection or capturing the knowledge, patterns of storage and distribution of knowledge and patterns of the application of knowledge [7] on figure 2. The knowledge creation model process begins with identifying the knowledge input that is required by the organization to support its business processes; followed by a process of knowledge storing as the capital of the organization. After the knowledge has been stored, it is then used to support the added value in the business, and through the creative process of learning during or learning after the output is obtained to reduplicate the benefits. This knowledge creation process occurs in three phases done to add the value of the business including:

(a)Learning Before Process: It is the effort to replicate the best practices on previous projects to ensure that this new project will be at least the same as the best practices of the previous project. Therefore, the proposal for the new project plan must be validated by experienced experts in using the best practices of the previous project (b)Learning During Process: It is the effort to find new experience/knowledge that is related to knowledge of best practices or work errors that are carried out with analysis to find ways to guide shifts/subsequent work assignments. This is used to minimize the monetization of errors or to detect work errors as early as possible; (c)Learning After Process: It is the effort to record core or special events from the experience of 
The $1^{\text {st }}$ International Conference on Business and Engineering Management (IConBEM 2020)

February $1^{\text {st }} 2020$, Institut Teknologi Sepuluh Nopember, Surabaya, Indonesia

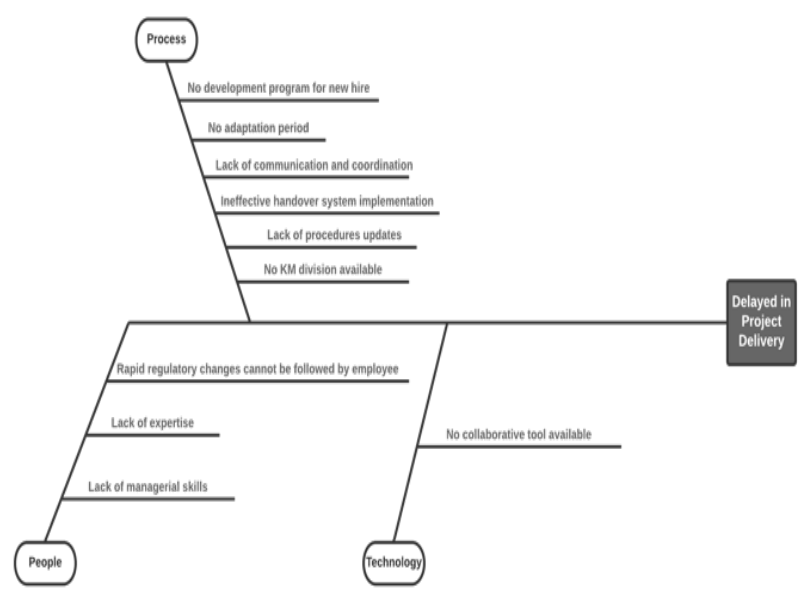

Figure 3. Fishbone Analysis at BSO Department.

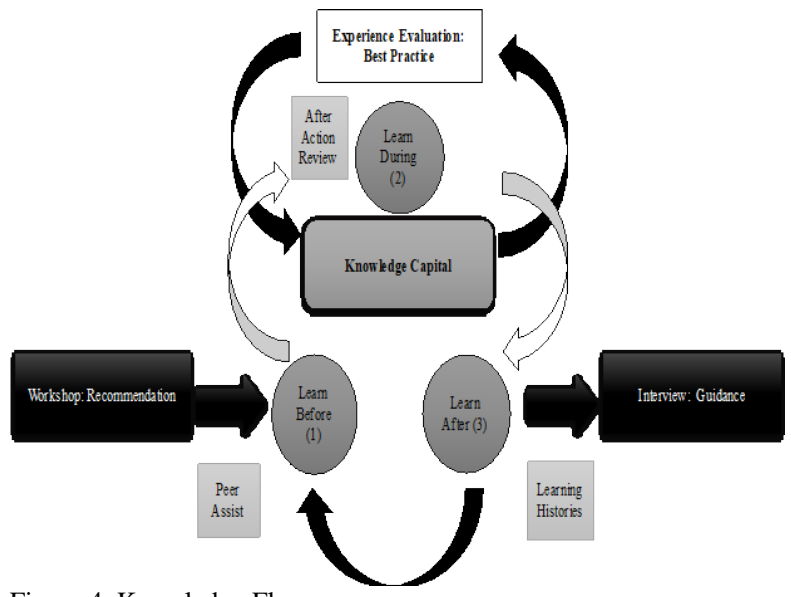

Figure 4. Knowledge Flow.

a project that has been completed, to be stored in a repository, and if there is a repetition of the project or something similar in the future, the previous project documentation will be very helpful to prepare the next project being worked on by replicating the best practice of the previous project. As a result, the tools of knowledge conversion mechanism (SECI) as the social interaction between individuals and knowledge flows as the type of communication that is connected to the diffusion of messages, products, individuals as well as the organization that comes up with new ideas, knowledge, concepts and so on in this case is used in this research to facilitate the knowledge transfer.

\section{METHOD}

As this research purpose is to overcome project delivery delays in the consulting firms using knowledge management perspective, the qualitative research method is used as it allows the existence of multiple subjective perspectives and construct knowledge from the people in the organizations (i.e. employee, management) where the data is derived from the data sources. By using this method, the researcher believe that it will help the researcher to capture better understanding on the effect of the project delivery delays and determine the suitable solution to overcome the problem. In this research, the data sources come from primary data, meaning that the data obtained directly by the researcher through interviews and observation and secondary data, which is the data that is obtained from other resources such as archive, on table 3 .

\section{RESULT AND DISCUSSION}

\section{A. Interview Results (Coding)}

The interview analysis begins identifying keywords and grouping them based on their resemblance. In this research, the researcher came up with 4 (four) groups. The resemblance of the keywords or codes is related to the research framework, in order to retrieve and categorized similar information, set a stage in further analysis and therefore draw conclusions. The conclusion of the analysis based on the interview on 11 interviewees using the coding process is described as the following groups on table 4 .

Fishbone diagrams is a diagram which provides a visual means of the causes of problem occurs in an organization. Renee (2010: 31) defines fishbone diagrams, also known as Ishikawa diagrams or cause-and-effect diagrams as one of the problem-solving tools that helps the organization to identify, organize and visualize the contributing causes and effects on a certain issue or event. In this case, based on the interview conducted at BDO Indonesia, the researcher summarized the following causes related to knowledge management that might leads to project delivery delay in consulting company:

Following to the fishbone analysis in figure 3, it can be seen that there are several possibilities that can cause delay in projet delivery in a consulting firm: (1)People: The rapid regulator changes cannot be followed by the employeecapability to adapt quickly this have a high effect on the completion of project as it occurs frequently, the lack of expertise on certain areas also causing delays in completion of project, each employee must learn from working directly in the fields with the clients and reflects on their mistakes, managers plays a big role in decision making of the company such as the decision in pricing, utilization of resources and so on, therefore it is important to have a high level of skills for the managers; (2)Process: The abstaint on the development program and adaptation period for the new hired can cause delay in completion of the project as it take a while for the newly hire to adapt to new situation in the company, there are lack of communication and coordination among members, the ineffectiveness of the handover system implementation combined with high employee turnover causing some delayed in the completion of projects. Procedures as a guideline to complete projects however it is not updated regularly. The abstaint of KM division in the department could also be the cause of delay in project delivery as the management of knowledge can sometimes be neglected; (3)Technology: The abstaint of collaborative tool available will cause delay in project delivery when it comes to the project completed with group or team members.

\section{B. Discussion}

Based on the interview and coding analysis as well as the fishbone analysis conducted the root cause of delays in project delivery can be seen in the table stated on table 5 . 
The $1^{\text {st }}$ International Conference on Business and Engineering Management (IConBEM 2020)

February $1^{\text {st }} 2020$, Institut Teknologi Sepuluh Nopember, Surabaya, Indonesia

The root cause stated above then connected to the KM objectives on table 6.After the root causes are described and connected with KM objectives, the KM framework is used as key components to ensure the continuity of knowledge management implementation. In the company, the KM framework is divided into three, which are, people, process \& technology. The people involved in the KM strategies are namely Managers, Consultants and Associates. The process \& technology used are based on the results of interviews and observations on table 7 . Following to that, knowledge conversion mechanism is used for the recurring project based on the interview and coding analysis as well as the fishbone analysis conducted on table 8 . Socialization in this case, there should be training, mentorship, and on-the-job training to ensure the capturing of knowledge of the employees. The forum discussion should be conducted in two types, monthly and when it is necessary to discuss about problem faced, completion of project and so on. The brainstorming, is needed to conduct and facilitate the division to stimulates the creative thinking or innovative solutions to the problem faced. Lastly, the knowledge café is added as the employees invited to the café as a gathering to connect people by possessing provocative questions that will be answered by the participants.

For the Externalization, handover documents, exit interview and draft procedure is a way to ease the transfer of knowledge. The draft of calendar is needed to monitor the progress of project completion per clients. The draft of newsletter will ensure the update on the regulation is written and known by the other members in the company. Best practice module is should be made by the top to mid-level management to create a module concerning the best practice or the successful experiences. The k-based exit interview is also included, as it allows to transfer of the knowledge of the employee that is going to leave the company to replicate them and transferred them to the employee that is going to replace their position. In the Combination, the availability of hard-disk allows member of the company to store the softcopy documents. While intranet in this case is the collaborative tool which can be used to share the knowledge. The most anticipated and requested tool that are discussed by the employees during the interview was to have a server, to allow knowledge sharing and documentation real-time. The procedure needs regularly with the current project's solutions. Update on regulations, in this case, is also needed to capture the regulations and its adjustment that have is rapidly changing. Whereas for the Internalization, the availability of websites allows not only the member of the organization to see the business process but also for the clients. Checking procedures is used for the members of theorganization to see the steps, timelines and process to complete a project. Checking best practice module means that the employee that is going to be involved in a project should check the module containing the best practices that are made by the managers and consultants in the previous projects. This is also the same process as to checking the lesson learn papers, the only difference is that the lesson learned consist of the mistakes as prevention.
The knowledge flows are described to minimize the knowlede management transfer issue regarding the completion of the non-recurring project. The knowledge flow to overcome the delay in project delivery can be described in the figures on figure 4 . With the explanation of KM strategies at the unit and project level, the corporate governance is described. In this case, the governance of KM exists to ensure the KM system to meet the organization's desired performance by maintaining the performance of KM. The knowledge flows occur in three phases adding value of the business, which are the followings on table 9 .

\section{CONCLUSION}

\section{A. Recommendation}

In this research, there are several recommendations related to the knowledge management strategy which should be implemented in order to overcome the KM transfer issue that results in a delay in project deliveries at consulting firms;(a) Importance of Knowledge Management Strategy. Based on the research, a knowledge management strategy needs to be performed by all of the members in the organization, as it turns the human capital into intellectual capital through the process of creating value and problemsolving; (b) Knowledge Management Implementation Plan. The implementation plan of knowledge management in the company should be treated as a compulsory to encourage the members in the organization to be involved and therefore gaining benefits from it. The knowledge management system needs to be used by everyone within the organization for it to be effective, it cannot only be done by the top-level management but it also has to be used by the mid to low level management, as more and more people involve and spread their tacit knowledge, the knowledge assets of the company will increase. To make the implementation plan as compulsory, this could be mean that it is included as one of the factors in key performance index of the company, this will not only ensure the participation but also stimulates the member of the organization to establish knowledge sharing culture; (c) Research Limitation. As this research is limited to the Business Service Outsourcing Department of BDO Indonesia. In order to identify further concerning the cause of delay in project delivery and how to overcome the issue, additional research on several consulting firm as well as depth research on the other studies related to project delivery is necessary in order to get a broader picture in order for overcoming project delivery delay.

\section{B. Conclusion}

To conclude, this research explains about the knowledge management system that can be used to overcome the problem related to the project delivery delays. In this case, the process of how knowledge transfer should be carried out through the expected knowledge conversion mechanism (SECI), Knowledge Flows and Knowledge Framework (People, Process \& Technology) is provided. The knowledge flows, in this case, are described to minimize the 
The $1^{\text {st }}$ International Conference on Business and Engineering Management (IConBEM 2020)

February $1^{\text {st }} 2020$, Institut Teknologi Sepuluh Nopember, Surabaya, Indonesia

knowledge management transfer issue that usually occurs during the completion of the non-recurring projects. The knowledge management framework is used as it explains the possible root cause of the delay in project deliveries. In this case, proposed problem solving can be found with the KM objectives based on the root cause drawn in the fishbone analysis. The knowledge management strategy that should be implemented in the company is drawn from the interview analysis, which later used on the KM framework analysis based on its key components which are people, process \& technology. The recommendation is described as material for further research relating to knowledge management and or other related disciplines.

\section{REFERENCES}

[1] I. I. Andone and V. D. Pavaloaia, "Outsourcing the Business Services,” vol. 14, pp. 163-171, 2010.
[2] F. R. Indriani, "Investment Realization in the First Quarter of 2019 Reached Rp 195 . 1 Trillion,” Jakarta, 2019.

[3] K. Erik Sveiby, "The intangible assets monitor," J. Hum. Resour. Costing Account., vol. 2, no. 1, pp. 73-97, Jan. 1997, doi: 10.1108/eb029036.

[4] M. B. Chouikha, Organizational Design for Knowledge Management. Hoboken: John Wiley \& Sons, Inc, 2016.

[5] I. Chan, "Management hybrid strategy with people, technology and process pillars," Knowl. Manag. Strateg. Appl., 2016, doi: 10.5772/intechopen.70072.

[6] D. Ardianto, "The role of knowledge management governance," Int J. Comput. Theory Eng., vol. 5, no. 1, pp. 133-137, 2013, doi: 10.7763/ijcte.2013.v5.662.

[7] J. H. \& D. K. Tjakraatmadja, Strategi Implementasi Knowledge Management, 1st ed. Bandung: Penerbit ITB, 2017.

[8] A. Chatterjee, A. Pereira, and B. Sarkar, "Learning transfer system inventory (LTSI) and knowledge creation in organizations," Learn. Organ., vol. 25, no. 5, pp. 305-319, 2018, doi: 10.1108/TLO-062016-0039.

[9] C. Karlsson and U. Gråsjö, "Knowledge flows, knowledge externalities, and regional economic development," Handb. Reg. Sci., pp. 413-437, 2014, doi: 10.1007/978-3-642-23430-9_25. 